\title{
INSULINOMA MISDIAGNOSED AS NEUROLOGIC DISEASE
}

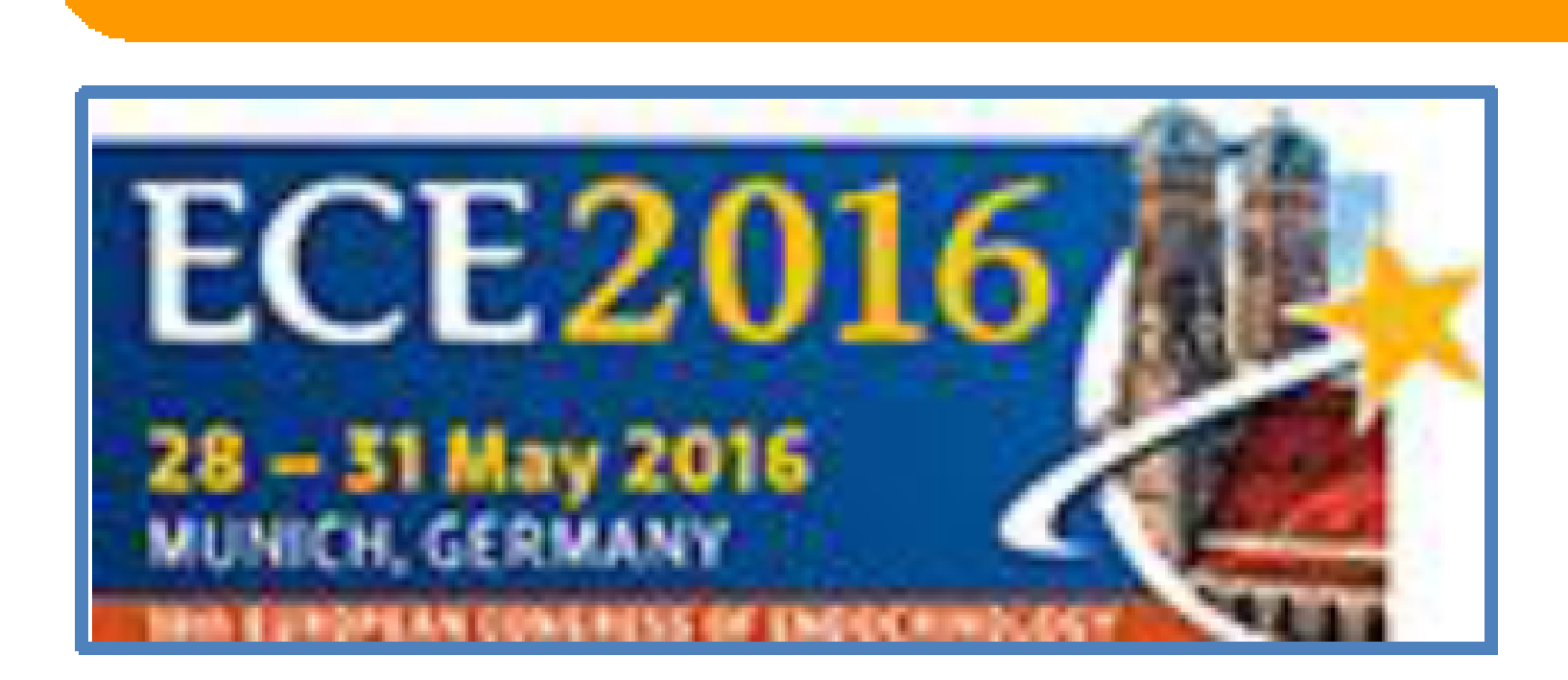

\section{ENDOCRINE TUMOURS}

\section{J. Salavessa ${ }^{1}$, V. Gomes², F. Ferreira² ${ }^{2}$ C. Alcântara ${ }^{1}$}

1 - Internal Medicine Department, Hospital de Santa Maria, CHLN - EPE, Lisbon, Portugal

2- Endocrinology, Diabetes and Metabolism Department, Hospital de Santa Maria, CHLN - EPE Lisbon, Portugal

SANTAMARIA

\section{INTRODUCTION}

Insulinoma is a rare pancreatic endocrine tumour derived from $\beta$ cells that secret insulin. Most are benign and solitary. ${ }^{1}$

The median age at diagnosis is about 47 years and it is more prevalent in women.,

The common clinical manifestation of insulinoma is Whipple's triad which consists of hypoglycemia, associated neuroglycopenic and sympathoadrenal symptoms and resolution of the clinical signs with the administration of glucose. ${ }^{3}$ Diagnosis relies on clinical features along with laboratory tests and imaging. However, the nonspecific symptoms and small size of these tumours can lead to difficulties of diagnosis and localization. ${ }^{1}$

\section{CASE REPORT}

\section{CLINICAL PRESENTATION}

- 84 year old male, admitted to the emergency department of a central Hospital in Lisbon (Portugal), with seizures.

- Previous history of fatigue, dizziness and tremors for the past two years, diagnosed as Parkinson's disease.

- Physical examination: Glasgow Coma Scale 13 (E 3; V 4; M 6), confusion, abnormal behaviour and severe hypoglycemia (44 mg/dL).

- The symptoms resolved after intravenous glucose administration.

\section{LABORATORY TESTS}

- 72 hour fast test showed increased levels of insulin, C-peptide and proinsulin, consistent with endogenous hyperinsulinism. (table 1).

- Screening for sulfonylurea, anti-insulin antibodies and anti-insulin receptor antibodies was negative.

- MEN 1 syndrome was excluded.

\begin{tabular}{ccc} 
Parameter & Patient & $\begin{array}{c}\text { Endogenous } \\
\text { Hyperinsulinism criteria }{ }^{2}\end{array}$ \\
Glucose & $38 \mathrm{mg} / \mathrm{dl}$ & $\leq 45 \mathrm{mg} / \mathrm{dL}$ \\
\hline Pro-insulin & $51,7 \mathrm{pmol} / \mathrm{L}$ & $\geq 5 \mathrm{pmol} / \mathrm{L}$ \\
\hline Insulin & $7,1 \mathrm{mUI} / \mathrm{L}$ & $\geq 3 \mathrm{mUl} / \mathrm{L}$ \\
\hline C-peptide & $2,21 \mathrm{ng} / \mathrm{mL}$ & $\geq 0,6 \mathrm{ng} / \mathrm{mL}$
\end{tabular}

Table 1: 72 hour fast test

\section{IMAGIOLOGY}

- Abdominal computed tomography (CT) scan: revealed a 12,1 mm hypervascular nodule in the uncinate process of the pancreas (figure

1).

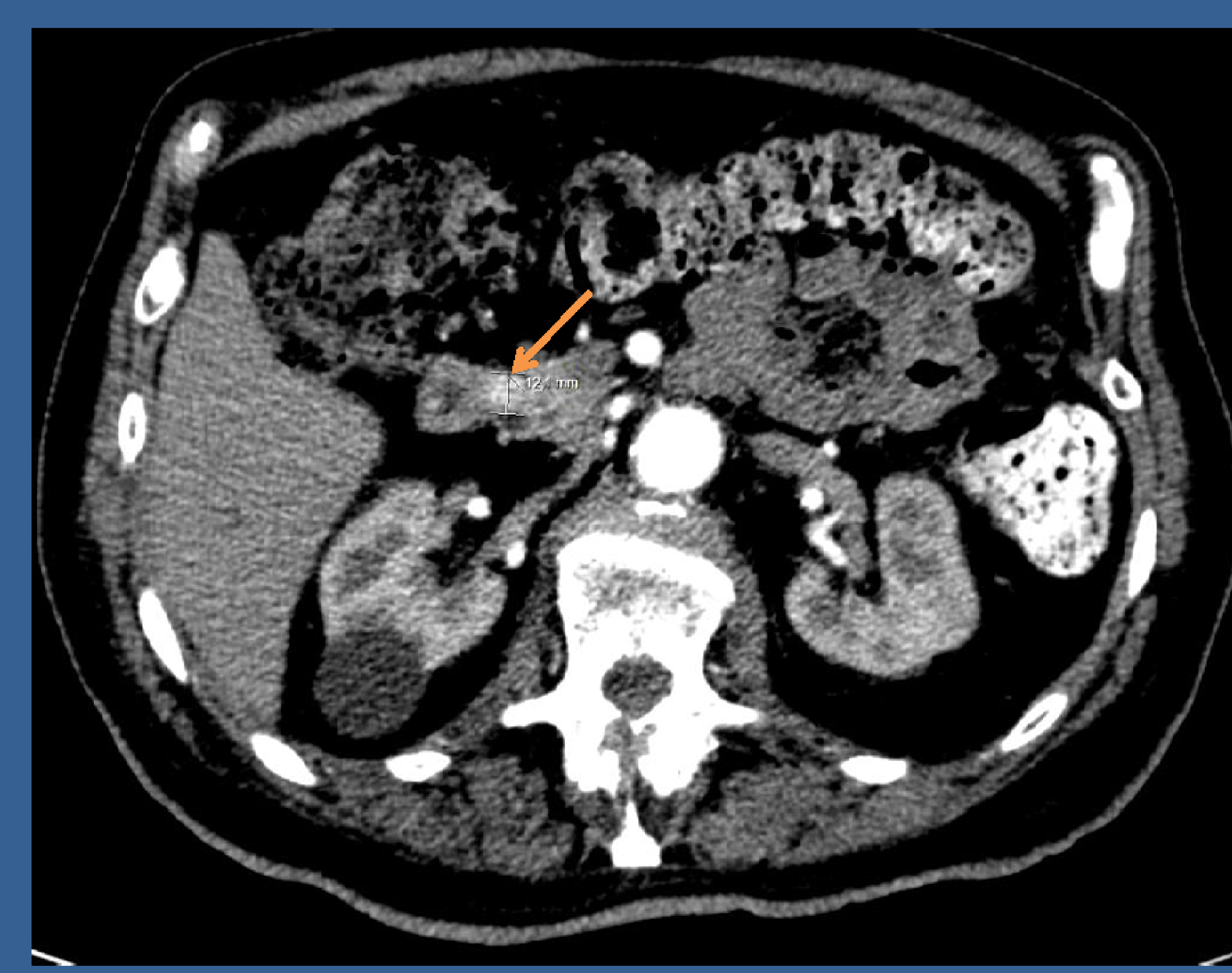

Figure 1: abdominal CT scan

- Endoscopic ultrasonography and biopsy: showed a hipoecogenic nodule with $12 \times 7 \mathrm{~mm}$ in the uncinate process of the pancreas. The histopathology was suggestive of a neuroendocrine tumour.

\section{TREATMENT}

- Medical therapy : Diazoxide (200 mg/day) and poli-fractionated diet until surgery.

- Surgery: enucleation of the pancreatic tumour. The histopathology was consistent with the diagnosis of benign insulinoma.

The clinical course was favourable, with regression of symptoms and blood glucose normalization, without medical therapy.

\section{CONCLUSION}

Insulinoma remains a diagnostic challenge since symptoms are nonspecific and may lead to incorrect diagnosis. As in this clinical case, a neurologic disease might be considered the culprit. Retrospectively, the patient's symptoms (fatigue, dizziness and tremors) can be interpreted as hypoglycemic episodes caused by the insulinoma. It is important to consider this diagnosis, because severe and sustained hypoglycemia can lead to disability and death. On the other hand, it is easily confirmed by standard endocrine tests and insulinoma can be potentially curable through surgical resection.

References:

1-Ramiro Carvalho, F. Branquinho et al. Insulinoma: a propósito de um caso clínico com revisão da literatura. Revista da sociedade portuguesa de medicina interna. Abr/jun 2010 2-Hypoglycemia in persons without diabetes, DynaMed, Updated 2015 Feb 23

3- Zonera Ashraf A. Insulinoma. Medscape. 2015 